УДК 616.314.18-002.4:615.262.1

DOI 10.11603/2311-9624.2019.2.10395

\author{
(C)А. М. Потапчук, Є. Л. Оніпко, М. Ю. Сабов, В. М. Алмаші, А. В. Юрженко, \\ М. О. Стецик \\ ДВНЗ «Ужгородський національний університет» \\ stomatkafedra@gmail.com
}

\title{
Біомаркери в діагностиці хвороб пародонта
}

Резюме. Хронічний перебіг пародонтиту та гінгівіту вражає до 80 \% дорослого населення, стаючи одним із найпоширеніших серед хвороб людства. Захворювання ініціюється накопиченням бактерій вздовж ясенного краю і в просторі між ясенними тканинами та зубами. Відсутність клініки гострого болю при захворюваннях пародонта є однією з основних причин низького рівня звернень пацієнтів за стоматологічною допомогою. Діагностику захворювань пародонта, як правило, проводить лікарстоматолог. Вона включає візуальний огляд тканин ясен та ряд інших протокольних процедур, у тому числі додоткових методів діагностики - клінічну оцінку рентенограми. Водночас, звичайні клінічні та рентгенографічні методи діагностики пародонта здатні лише до ретроспективного діагнозу, вони не можуть виявити або передбачити активність пародонтиту. Тому в останні роки активно досліджують потенційні біомаркери для діагностування хвороб тканин пародонта. Джерелом біомаркерів перш за все є ясенна рідина та слина, як такі, що безпосередньо контактують з ураженими тканинами. Враховуючи сказане, доцільно проаналізувати літературні дані щодо біомаркерів ясенної рідини та слини, які використовують для діагностики хвороб пародонта та можливості розробити прості у застосуванні тест-методи для ранньої діагностики.

Мета дослідження - проаналізувати літературні дані щодо оцінки перспективи застосування біомаркерів у стоматологічній практиці, зокрема в діагностиці патології тканин парадонта разом із періімплантною патологією.

Матеріали і методи. У дослідженні застосовано бібліосематичний та аналітичний методи.

Результати досліджень та їх обговорення. У статті проаналізовано та опрацьовано джерела науково-медичної інформації, що стосуються застосування біомаркерів у діагностиці хвороб пародонта.

Висновки. Незважаючи на те, що в діагностиці рогової рідини наявна значна кількість потенційних біомаркерів, проведені на сьогодні дослідження виявилися недостатніми щодо надання клінічно достовірної та корисної інформації для практиків з точки зору більш точної діагностики та планування лікування.

Ключові слова: біомаркер; ясенна рідина; слина; пародонт; пародонтит.

\section{(C)А. М. Потапчук, Е. Л. Онипко, М. Ю. Сабов, В. М. Алмаши, А. В. Юрженко, Н. А. Стецик}

ГВУз «Ужгородский национальный университет»

\section{Биомаркеры в диагностике болезней пародонта}

Резюме. Хроническое течение пародонтита и гингивита поражает до 80 \% взрослого населения, ставши одной из самых распространенных болезней человечества. Заболевания инициируется накоплением бактерий вдоль десневого края и в пространстве между десневыми тканями и зубами. Отсутствие клиники острой боли при заболеваниях пародонта является одной из основных причин низкого уровня обращений пациентов за стоматологической помощью. Диагностику заболеваний пародонта, как правило, проводит врач-стоматолог. Она включает визуальный осмотр тканей десен и ряд других протокольных процедур, в том числе дополнительных методов диагностики клиническую оценку рентенограммы. В то же время, обычные клинические и рентгенографические методы диагностики пародонта способны лишь к ретроспективному диагнозу, они не могут обнаружить или предсказать активность пародонтита. Поэтому в последние годы активно исследуются потенциальные биомаркеры для диагностики болезней тканей пародонта. Источником биомаркеров в первую очередь является десневая жидкость и слюна, как такие, которые непосредственно контактируют с пораженными тканями. Учитывая сказанное, целесообразно проанализировать литературные данные по биомаркерам десневой жидкости и слюны, которые используют для диагностики болезней пародонта и возможности разработать простые в применении тест-методы для ранней диагностики. 
Цель исследования - проанализировать литературные данные по оценке перспективы применения биомаркеров в стоматологической практике, в частности в диагностике патологии тканей пародонта вместе с периимплантной патологией.

Материалы и методы. В исследовании применены библиосематический и аналитический методы. Результаты исследований и их обсуждение. В статье проанализированы и обработаны источники научно-медицинской информации, касающиеся применения биомаркеров в диагностике болезней пародонта.

Выводы. Несмотря на то, что в диагностике ротовой жидкости имеется значительное количество потенциальных биомаркеров, проведенные на сегодняшний день исследования оказались недостаточными для предоставления клинически достоверной и полезной информации для практиков с точки зрения более точной диагностики и планирования лечения.

Ключевые слова: биомаркер; десневая жидкость; слюна; пародонт; пародонтит.

\author{
(C)A. M. Potapchuk, Ye. L. Onipko, M. Yu. Sabov, V. M. Almashi, A. V. Yurzhenko, \\ M. O. Stecique \\ Uzhhorod National University
}

\title{
Biomarkers in the diagnosis of periodontal diseases
}

Summary. The chronic course of periodontitis and gingivitis affects up to $80 \%$ of the adult population, making them one of the most common diseases of mankind. The disease is initiated by the accumulation of bacteria along the gingival margin and in the space between the gingival tissue and the teeth. The absence of an acute pain clinic for periodontal diseases is one of the main reasons for the low level of patients seeking dental care. Diagnosis of periodontal disease, as a rule, is carried out by a dentist, it includes a visual examination of the gum tissue and a number of other protocol procedures, including additional diagnostic methods - a clinical assessment of the roentgenogram. At the same time, conventional clinical and radiographic methods for periodontal diagnostics are capable of only a retrospective diagnosis, they cannot detect or predict the activity of periodontitis. For these reasons, in recent years, potential biomarkers for the diagnosis of periodontal tissue diseases have been actively investigated. The source of biomarkers, in the first place, are considered gingival fluid and saliva, such as those that are in direct contact with the affected tissues. Given the foregoing, it seems appropriate to review the literature on biomarkers of gingival fluid and saliva used to diagnose periodontal diseases and the possibility of developing easy-to-use test methods for their early diagnosis.

The aim of the study - to evaluate the prospects of using biomarkers in dental practice, in particular in the diagnosis of parathon tissue pathology, including peri-implant pathology, based on the analysis of literature data.

Materials and Methods. The study used biblical and analytical methods.

Results and Discussion. The sources of scientific and medical information on the application of biomarkers in the diagnosis of periodontal diseases are analyzed and processed.

Conclusions. Despite the fact that the diagnostic value of oral fluids is recognized and there is a significant number of potential biomarkers, the studies conducted to date have proved inadequate to provide clinically reliable and useful information for practitioners in terms of more accurate diagnosis and treatment planning.

Key words: biomarker; periodontal; gingival crevice fluid; saliva.

Вступ. Діагностика є одним із найактуальніших завдань охорони здоров’я, що спонукає до пошуку нових методик та методів завчасно виявити різноманітні захворювання. У цьому аспекті в останні роки стрімко розвиваються біомедичні дослідження щодо застосування біомаркерів. Згідно 3 визначенням, запропонованим спеціальною робочою групою Biomarkers Definitions Working Group Національного інституту здоров'я США, біомаркер - це об'єктивно вимірювана характеристика, що є індикатором нормальних та патологічних біологічних процесів, а також результату фармакологічної корекції захворювання [1]. Доречно також навести класифікацію біомаркерів, запропоновану тією ж самою робочою групою:

- 0 тип - маркер, що вказує на наявність захворювання і корелює з його клінічними проявами;

- I тип - маркер, пов’язаний із терапевтичним ефектом і механізмом дії препарату; 
- II тип (предиктор клінічного результату, «surrogate endpoint», згідно 3 термінологією англомовних авторів) - маркер, що дозволяє передбачити сприятливий або несприятливий результат захворювання, ефективність лікування [2].

Дана класифікація враховує ділянки для застосування біомаркерів. Як видно, крім діагностичної функції, вони дозволяють оцінити стан пацієнта під час лікування, визначити так звані clinical endpoints, показати можливий результат захворювання і передбачувані результати терапії, вони також дозволяють оцінити безпеку терапії. Необхідно відмітити, що в цьому аспекті їх застосування ще потребує багато доопрацювань [2]. Серед переваг використання біомаркерів $є$ можливість неінвазійного відбору проб для дослідження.

До загальних властивостей біомаркерів належить їх специфічний зв'язок із патологією, чутливість, доступність у застосуванні для осіб різної статі й віку, однозначність ідентифікації, висока роздільна здатність методу визначення, сумісність 3 наявним лабораторним обладнанням, а також можливість визначити біомаркери як в гострій фазі захворювання, так і при ремісії.

Якщо їх використовують в умовах, які становлять небезпеку для життя пацієнта, то вони повиненні бути максимально чутливими, вирішальним є правило "rule out». Ціна помилкової діагностики здоров’я в даному випадку перевищує вартість додаткового тестування або помилкового діагнозу захворювання. У діагностиці та клініці часто використовують ізоферменти, за їх показником можна судити про ушкодження тканини. Ферменти як біомаркери дозволяють генетично охарактеризувати популяцію людини, виявити рівень типів, схильних до впливу того чи іншого зовнішнього фактора, показати генетичну різноманітність вибірки.

Інтерес до цієї теми зумовив і появу спеціальних журналів: «Biomarkers», «The International Journal of Biological Markers». Бioмаркери слугують широкому ряду цілей при розробці ліків і оцінці терапевтичної стратегії. Вони можуть забезпечити основу для відбору кандидатів на клінічні випробування i виявлення типів захворювань, а також для пацієнтів, які $є$ найбільш придатними для застосування нових препаратів.

Деструктивні процеси в тканинах пародонта метаболічні процеси в кістковій тканині альвеолярного відростка тісно пов'язані зі структурно-функціональним станом кісткової системи організму, з активністю метаболічних процесів та інтенсивністю ремоделювання кісток скелета [21, 22]. Оцінку структурнофункціонального стану кісткової тканини проводять за допомогою маркерів метаболізму кісткової тканини, які відображають інтенсивність резорбції і кісткоутворення. Основною ланкою в розвитку деструктивних змін кісткової тканини у більшості випадків $€$ підвищення резорбції кісткових структур або зниження кісткоутворення, або різні патологічні прояви при ремоделюванні кісткової тканини [21-24]. Однак в імплантології для визначення показань і протипоказь, для зменшення й попередження ускладнень стан процесів ремоделювання кісткової тканини не враховували. Тому комплексне вивчення маркерів активності резорбції і процесів кісткоутворення дозволить розкрити особливості мінеральної щільності альвеолярних кісткових тканин і дасть можливість прогнозувати результати імплантації та забезпечити довготривалу стабілізацію імплантів та зниження періімплантних ускладнень.

Метою дослідження було проаналізувати літературні дані щодо оцінки перспективи застосування біомаркерів у стоматологічній практиці, зокрема в діагностиці патології тканин парадонта разом із періімплантною патологією.

Матеріали і методи. У дослідженні застосовано бібліосематичний та аналітичний методи.

Результати досліджень та їх обговорення. 3 точку зору огляду джерел щодо біомаркерів, то одним із найперспективніших напрямків $€$ дослідження рідин ротової порожнини, а саме, ясенної рідини та слини. Вперше припущення, що аналіз ясенної рідини може бути використано для кількісної оцінки запального стану тканин ясен і пародонта було висловлено у 1960 р. [3]. Наявність і функцію білків, особливо ферментів, у ньому вперше досліджували J. S. Bang, G. Cimasoni [4]. Було доведено, що ферменти ясенної рідини кількісно характеризують стан ясен і пародонта. L. M. Golub [5], K. Ohlsson, I. Olsson [6], V. J. Uitto, A. M. Raeste [7] виявили, що колагеназа та еластаза потрапляють у ясенну рідину із клітин і їх активність корелює із запаленням ясен. Ясенна рідина містить велику кількість клітинних і біохімічних компонентів, які можуть бути 
індикаторами метаболізму в тканинах пародонта. Вони є потенційними діагностичними або прогностичними маркерами нормального і патологічного стану пародонта [8]. У якості потенційних маркерів було досліджено понад 65 компонентів ясенної рідини для діагносту- вання періодонтиту [3] (табл.). Ці компоненти поділяють на 3 загальні категорії:

1. «Host-derived»-ферменти та їх інгібітори;

2. Збудники запалення і модифікатори реакції господаря;

3. Продукти розпаду тканин.

Таблищя. Біомаркери ясенної рідини

\begin{tabular}{|c|c|c|}
\hline $\begin{array}{l}\text { «Host-derived»-ферменти i ïx } \\
\text { інгібітори }\end{array}$ & $\begin{array}{c}\text { Збудники запалення і модифіка- } \\
\text { тори реакції тканин }\end{array}$ & Продукти розкладу тканин \\
\hline $\begin{array}{l}\text { Аспартатамінотрансфераза } \\
\text { Лужна фосфатаза } \\
\text { Кисла фосфатаза } \\
\beta \text {-глюкуронідаза } \\
\text { Еластаза } \\
\text { Інгібітор еластази } \\
\text { a }- \text {-макроглобулін }_{\text {a }} \text { - інгібітор протеїнази } \\
\text { Катепсини } \\
\text { Цистеїнові протеїнази (В,H,L) } \\
\text { Серинова протеїназа (G) } \\
\text { Катепсин D } \\
\text { Ферменти, що розкладають іму- } \\
\text { ноглобулін } \\
\text { Глікозидази } \\
\text { Дипептидилпептидази } \\
\text { Неспецифічні нейтральні про- } \\
\text { теїнази } \\
\text { Колагенази } \\
\text { Матриксні металопротеїнази } \\
\text { (МмП-1, ММП-3, ММП-8, ММП-13, } \\
\text { ММП-2, ММП-9, МмП-10, ММП-11) } \\
\text { Желатинази } \\
\text { Арилсульфатаза } \\
\text { Мієлопероксидаза } \\
\text { Лактатдегідрогеназа } \\
\text { в-N-ацетил-гексозамінідаза }\end{array}$ & 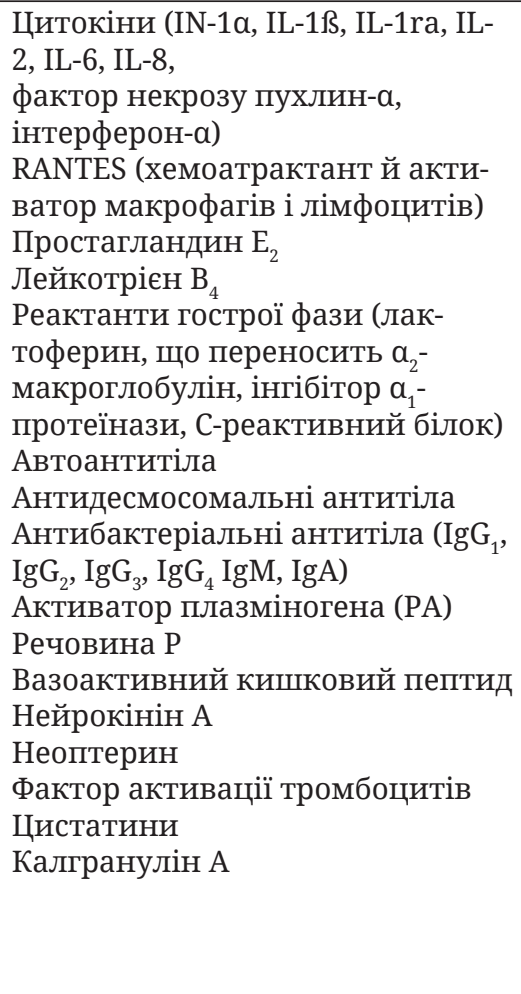 & $\begin{array}{l}\text { Глікозаміноглікан } \\
\text { Гіалуронова кислота } \\
\text { Хондроїтин-4-сульфат } \\
\text { Хондроїтин-6-сульфат } \\
\text { Дерматан сульфат } \\
\text { Гідроксипролін } \\
\text { Фібронектинові фрагменти } \\
\text { Білки сполучної тканини і кісток } \\
\text { Остеонектин, остеокальцин } \\
\text { Пептиди колагену типу } 1 \\
\text { Остеопонтин } \\
\text { Ламінін } \\
\text { Кальпротектин } \\
\text { Пептиди гемоглобіну } \\
\beta \text {-ланцюга } \\
\text { Піридинолінові структури }\end{array}$ \\
\hline
\end{tabular}

Було встановлено, що наявність ліпополісахаридів (ендотоксинів) корелює із запаленням ясен [9]. У пацієнтів з локалізованим агресивним пародонтитом збільшується рівень антитіл ліпополісахариду та інгібітора інтерлейкіну-1. Бактерійні протеїнази, зазвичай, належать до ендопептидазного типу і складають основу діагностичного L-BANA-тесту [10]. Метаболічні кінцеві продукти вуглеводів, ліпідів і білків, які включають H2S, бутират і пропріонат, показують позитивну кореляцію між ступенем запалення й об’ємом ясенної рідини.

Щодо біомаркерів з тканин, то вміст лужної фосфатази корелює зі збільшенням запалення в експериментальній моделі гінгівіту. В сироватці фермент пов'язаний із захворюванням кісток і його підвищення в ясенній рідині цілком може відображати зміни альвеолярної кістки в локалізованій ділянці [8].
Дослідження ферментів, що розкладають глікоген, такі як $\beta$-глюкуронідаза, показали значне збільшення вищевихідних значень приблизно через два-чотири тижні після початку запалення [10]. Автори [11] зазначають 10-разове збільшення рівня катепсину D, порівняно 3 початковим, спостереження корелювало 3 глибиною кишені. Було також виявлено, що концентрація лактоферину збільшується вдвічі в місцях, де наявний гінгівіт, періодонтит і локалізований агресивний пародонтит. Встановлено, що концентрації глікозаміногліканів підвищуються при агресивних захворюваннях пародонта.

Перспективними у якості біомаркерів $є$ речовини, пов'язані з тканинами пародонта. Найважливішим структурним білком пародонта $є$ колаген, що, зазвичай, визначають за гідроксипроліном. Встановлено, що рівень гідроксипроліну в пацієнтів до, через місяць і че- 
рез шість місяців після періодонтальної хірургії зменшується у часі [12]. Ферментами, що переважають при пародонтиті, є желатинази, що вивільняються із фібробластів (ММП-2), епітеліальних клітин (ММП-9 і ММП-2) і нейтрофілів (ММП-9). Протеоглікани мають здатність зв'язувати більшість колагенів, а також фібронектин. Після деградації тканин пародонта вивільняються глікозаміноглікани, які проникають у ясеннну рідину [13]. Дослідження, проведені на тваринах $[14,15]$ і людях [16, 17], показали, що хондроїтин-4-сульфат - головний глікозаміноглікан у нелікованих ділянках хронічного пародонтиту.

У майбутньому передбачається, що методи визначення біомаркерів кісткової тканини в ясенній рідині стануть більш чутливими, щоб дати точні діагнози.

Ще одним легкодоступним джерелом біомаркерів є слина. В останні роки на основі слини розроблено тест-методи, зокрема, для діагностики ВІЛ [18]. Оскільки слина безпосередньо близька до ділянок, які мають запалення ясен та пародонта; тому вона містить біологічні маркери, пов'язані з цими захворюваннями. Більш того, слина являє собою велику кількість рідини, яку легко збирати та зберігати, що робить її зручним для проведення високочутливого скринінгового тесту на захворювання пародонта. У перспективі багато дослідників вважає слину тим джерелом біомаркерів, що дозволить перетворити діагностику захворювань пародонта на тест, подібний до тесту на вагітність, коли позитивний результат тесту вказує на необхідність звернутись до лікаря, щоб підтвердити вагітність та отримати відповідну допомогу. Перешкоджає цьому те, що перетворення гінгівіту в пародонтит і прогресування втрати кісткової тканини при пародонтиті є явищами, які досі не повністю зрозумілі в патогенезі захворювання пародонта. Очевидно, що більшість випадків нелікованого та тривалого гінгівіту перетворюється на певний ступінь пародонтиту, і однозначно, що для такої конверсії необхідна наявність бактерій. Однак зрозуміло, що бактерійна біоплівка, не єдиний і навіть недостатній фактор, що стимулює перетворення гінгівіту в пародонтит. Інші фактори, зокрема реакція імунної системи людини, може бути більш визначальними. Відомо, що після початку пародонтиту, руйнування тканин пародонта не є ні лінійним, ні передбачуваним. Здебільшого руйнування тканин при пародонтиті відбувається у деяких періодах активності, що відбувається протягом відносно коротких періодів часу. Основні фактори, що спричиняють хворобу, як і раніше залишаються невстановленими. Спроби знайти кореляцію між активністю захворювання та мікробіологічними показниками, вміст ферментів, тощо не дали бажаного результату [19]. 3 усіх оцінених параметрів кровотеча при зондуванні $€$ найбільш точною ознакою захворювання пародонта (тобто його відсутність дуже добре передбачає відсутність деструкції тканин пародонта). Водночас, слина залишається важливим і зручним засобом для одночасного оцінювання безлічі факторів, які свідчать про періоди активності при прогресуванні пародонтиту. Це означає, що для діагностики аналіз потрібно здійснювати за комплексом біомаркерів й існуючих на сьогодні тест-методами, що включають додаткове лабораторне дослідження зразків, зокрема ПлР (полімеразна ланцюгова реакція) - аналіз [20].

Висновки. Незважаючи на те, що в діагностиці ротової рідини наявна значна кількість потенційних біомаркерів, проведені на сьогодні дослідження виявили недостатніми щодо надання клінічно достовірної та корисної інформації для практиків з точки зору більш точної діагностики та планування лікування. Основні проблеми діагностики за допомогою слини, поточні тести, що базуються на невеликій кількості потенційних біомаркерів; тести вони засновані на загальних мікробних і запальних цитокінах, які можуть і не бути специфічними для захворювання. Стосовно біомаркерів ясенної рідини, то їх значно більше, однак у більшості випадків вони чутливі й до інших патологій. Необхідною є також валідація біомаркерів, що потребуватиме широкомасштабних досліджень та порівняння 3 існуючими діагностичними методиками. Незважаючи на проблеми, використання біомаркерів на основі ротової рідини є перспективним для подальшого застосування для діагностики захворювань пародонта та прогнозування результатів їх лікування.

На наш погляд, поняттям «біомаркери» не варто замінювати клінічні показники, що відображають реальний стан пацієнта, його самопочуття і функціонування його організму. 


\section{Список літератури}

1. Biomarkers and surrogate endpoints: Preferred definitions and conceptual framework // Biomarkers Definitions Working Group: Clinical Pharmacology \& Therapeutics. - 2001. - Vol. 69, No. 3. - P. 89-95.

2. Мирошныченко И. И. Биомаркеры в современной медико-биологической практике / И. И. Мирошныченко, С. Н. Птицына // Биомедицинская книга. - 2009. - Т. 5, вып. 4. - С. 425-440.

3. Armitage G. Analysis of gingival crevice fluid and risk of progression of periodontitis / G. Armitage // Periodontology. - 2000. - Vol. 34. - P. 109-119.

4. Bang J. S. Total protein in human crevicular fluid / J. S. Bang, G. Cimasoni // J. Dent. Res. - 1971. - Vol. 50 (6). - P. 1683.

5. Some characteristics of collagenase activity in gingival crevicular fluid and its relationship to gingival diseases in human / L. M. Golub, K. Siegel, N. S. Ramamurthy, I. D. Mandel // J. Dent. Res. - 1976. - Vol. 55. - P. 10491057.

6. Ohlsson K. Neutrophil leukocyte collagenase, elastase and serum protease inhibitors in human gingival crevices / K. Ohlsson, I. Olsson, G. Tynelius-Bratthall // Acta Odontol. Scand. - 1973. - Vol. 31. - P. 51-59.

7. Uitto V. J. Activation of latent collagenase of human leukocytes and gingival fluid by bacterial plaque / V. J. Uitto, A. M. Raeste // J. Dent. Res. - 1978. - Vol. 57. - P. 844-851.

8. Embery G. GCF- Biomarkers of periodontal disease activity / G. Embery, R. Waddington // Adv. Dent. Res. 1994. - Vol. 8 (2). - P. 329-336.

9. The role of endotoxins in periodontal disease. III. Correlation of the quantity of endotoxin in human gingival exudate with the histologic degree of inflammation / B. Simon, H. Goldman, M. Ruben, E. J. Baker // Periodontol. - 1971. - Vol. 42. - P. 210-216. 10. Lamster I.B. Diagnosis of periodontal disease based on analysis of host response / I. B. Lamster, J. T. Grbic // Periodontology. - 2000. - Vol. 7, Issue 1. - P. 83-99.

11. Ishikawa I. Possible role of lysosomal enzymes in the pathogenesis of periodontitis. A study on cathepsin D in human gingival fluid / I. Ishikawa, G. Cimasoni, C. Ahmad-Zadeh // Arch. Oral Biol. - 1972. - Vol. 17. P. 111-117.

12. Hara K. Hydroxyproline content in gingival exudate before and after periodontal surgery / K. Hara, T. Takahashi // J. Periodontal Res. - 1975. - Vol. 10. P. 270-274.

13. Biomarkers in Gingival Crevicular Fluid /

\section{References}

1. (2001). Biomarkers and surrogate endpoints: Preferred definitions and conceptual framework. Biomarkers Definitions Working Group: Clinical Pharmacology \& Therapeutics, 69, 3, 89-95.

2. Mirishnichenko, I.I., \& Ptitsyna, S.N. (2009). Biomarkery $\mathrm{v}$ sovremennoy mediko-biologicheskoi praktike [Biomarkers in modern medical and biological practice]. Biomeditsinskaya khimiya - Biomedical Chemistry, 55, 4, 425-440 [in Russian].

3. Armitage, G. (2000). Analysis of gingival crevice fluid and risk of progression of periodontitis. Periodontology, 34, 109-119.
A. P. Kurdukar, A. A. Kurdukar, S. A. Mahale, A. M. Beldar // Journal of Dental and Medical Sciences. - 2015. - Vol. 14, Issue 10. - P. 104-109.

14. Connective tissue-associated proteins in crevicular fluid: potential markers for periodontal diseases / M. A. Bowers, L. W. Fisher, J. D. Termine, M. J. Somerman // J. Periodontol. - 1989. - Vol. 60. - P. 448451.

15. Kaufman E. Analysis of saliva for periodontal diagnosis - a review [In Process Citation] / E. Kaufman, I. B. Lamster // J. Clin. Periodontol. - 2000. - Vol. 27. P. 453-465.

16. ELISA detection of glycosaminoglycan (GAG) -linked proteoglycans in gingival crevicular fluid / T. Shibutani, W. Nishino, M. Shiraki, Y. Iwayama // J. Periodontal Res. - 1993. - Vol. 28. - P. 17-20.

17. Embery G. Biochemical markers of periodontal tissue destruction / G. Embery, K. S. Last // Dent. Update. - 1989. - Vol. 16. - P. 167-172.

18. Kim J. J. Salivary biomarkers in the diagnosis of oeriodontal diseas / J. J. Kim, C. J. Kim, P. M. Camargo // J. Calif. Dent. Assoc. - 2013. - Vol. 41 (2). - P. 119-124.

19. Armitage G. C. Periodontal diseases: diagnosis / G. C. Armitage // Ann. Periodontol. - 1996. - Vol. 1 (1). P. 37-215.

20. Nabors T. W. Salivary testing for periodontal disease diagnosis and treatment / T. W. Nabors, R. C. McGlennen, D. Thompson // Dent. Today. - 2010. - Vol. 29 (6). P. 53-60.

21. Поворознюк В. В. Костная система и заболевания пародонта / В. В. Поворознюк, И. П. Мазур // Монография. - Киев, 2004. - С. 446.

22. Потапчук А. М. Періімплантатна патологія. Ужгородський державний університет / А. М. Потапчук // Вісник стоматології. - 2000. - Т. II. - С. 70- 73.

23. Prognosis of possible implant loss after immediate placement by the laboratorial blood analysis and evaluation of intraoperatively derived bone samples / A. Potapchuk, V. Rusyn, M. Goncharuk-Khomyn, V. Hegedus // Journal of International Dental and Medical Research. - 2019. - Vol. 12 (1). - P. 143-150.

24. Рання дезінтеграція дентальних імплантатів та біохімічні чинники ризику / А. М. Потапчук, В. В. Русин, В. М. Криванич [та ін.] // Тези ювілейної міжнародної науково-практичної конференції «Стоматологія - вчора, сьогодні і завтра, перспективи розвитку». - Івано-Франківськ, 2009. - С. 168-169.

4. Bang, J.S., \& Cimasoni, G. (1971). Total protein in human crevicular fluid. J. Dent. Res., 50 (6), 1683.

5. Golub, L.M., Siegel, K., Ramamurthy, N.S., \& Mandel, I.D. (1976). Some characteristics of collagenase activity in gingival crevicular fluid and its relationship to gingival diseases in human. J. Dent. Res., 55, 1049-1057. 6. Ohlsson, K., Olsson, I., \& Tynelius-Bratthall, G. (1973). Neutrophil leukocyte collagenase, elastase and serum protease inhibitors in human gingival crevices. Acta Odontol. Scand., 31, 51-59.

7. Uitto, V.J., \& Raeste, A.M. (1978). Activation of latent collagenase of human leukocytes and gingival fluid by 
bacterial plaque. J. Dent. Res., 57, 844-851.

8. Embery, G., \& Waddington, R. (1994). GCF- Biomarkers of periodontal disease activity. Adv. Dent. Res., 8 (2), 329336.

9. Simon, B., Goldman, H., Ruben, M., \& Baker, E. (1971). The role of endotoxins in periodontal disease. III. Correlation of the quantity of endotoxin in human gingival exudate with the histologic degree of inflammation. J. Periodontol, 42, 210-216.

10. Lamster, I.B., \& Grbic, J.T. (2000). Diagnosis of periodontal disease based on analysis of host response. Periodontology, 83-99.

11. Ishikawa, I., Cimasoni, G., \& Ahmad-Zadeh, C. (1972). Possible role of lysosomal enzymes in the pathogenesis of periodontitis. A study on cathepsin D in human gingival fluid. Arch. Oral Biol., 17, 111-117.

12. Hara, K., \& Takahashi, T. (1975). Hydroxyproline content in gingival exudate before and after periodontal surgery. J. Periodontal Res., 10, 270-274.

13. Kurdukar, P.A., Kurdukar, A.A., Mahale, S.A., \& Beldar, A.M. (2015). Biomarkers in Gingival Crevicular Fluid. Journal of Dental and Medical Sciences, 14, 10, 104-109.

14. Bowers, M.A., Fisher, L.W., Termine, J.D., \& Somerman, M.J. (1989). Connective tissue-associated proteins in crevicular fluid: potential markers for periodontal diseases. J. Periodontol., 60, 448-451.

15. Kaufman, E., \& Lamster, I.B. (2000). Analysis of saliva for periodontal diagnosis - a review. J. Clin. Periodontol., 27, 453-465.

16. Shibutani, T., Nishino, W., Shiraki, M., \& Iwayama, Y. (1993). ELISA detection of glycosaminoglycan (GAG) -linked proteoglycans in gingival crevicular fluid. J. Periodontal Res., 28, 17-20.

17. Embery, G., \& Last, K.S. (1989). Biochemical markers of periodontal tissue destruction. Dent. Update, 16, 167 172.

18. Kim, J.J., Kim, C.J., \& Camargo, P.M. (2013). Salivary biomarkers in the diagnosis of oeriodontal diseas. J. Calif. Dent. Assoc., 41 (2), 119-124.

19. Armitage, G.C. (1996). Periodontal diseases: diagnosis. Ann. Periodontol, 1 (1), 37-215.

20. Nabors, T.W., McGlennen, R.C., \& Thompson, D. (2010). Salivary testing for periodontal disease diagnosis and treatment. Dent. Today, 29 (6), 53-60.

21. Povoroznyuk, V.V., \& Mazur, I.P. (2003). Kostnaya systema $i$ zabolevaniya parodonta [Bone system and periodontal disease]. Kiev: Monografiya [in Russian].

22. Potapchuk, A.M. (2000). Peryimplantatna patolohiia [Periimplant pathology]. Uzhhorodskyi derzhavnyi universytet. Visnyk stomatolohii - Uzhhorod State University. Bulletin of Dentistry, II, 70-73 [in Ukrainian]. 23. Potapchuk, A., Rusyn, V., Goncharuk-Khomyn, M., \& Hegedus, V. (2019). Prognosis of possible implant loss after immediate placement by the laboratorial blood analysis and evaluation of intraoperatively derived bone samples. Journal of International Dental and Medical Research, 12 (1), 143-150.

24. Potapchuk, A.M., Rusyn, V.V., Krivanych, V.M., Kikineshi, V., \& Yakim, M.M. (2009). Rannia dezintehratsiia dentalnykh implantativ ta biokhimichni chynnyky ryzyku [Early disintegration of dental implants and biochemical risk factors]. Tezy yuvileinoi mizhnarodnoi naukovo-praktychnoi konferentsii "Stomatolohiia - vchora, siohodni ta zavtra. Perspektyvni napriamky rozvytku" - "Abstracts of the jubilee international scientific-practical conference Dentistry - yesterday, today and tomorrow. Prospects development“, (pp. 168-169) [in Ukrainian].

Отримано 15.05.19 